\title{
Cash flows and leverage adjustments
}

\author{
Farnoush Amini Sharifi ${ }^{\mathrm{a}}$ and Seyedeh Mahbubeh Jafari ${ }^{* *}$
}

\begin{abstract}
${ }^{a}$ Masters Student, Department of Management and Accounting, South Tehran Branch, Islamic Azad University, Tehran, Iran ${ }^{b}$ Faculty member, Department of Management and Accounting, South Tehran Branch, Islamic Azad University, Tehran, Iran

\section{H R O N I C L E}

Article history:

Received December 5,2015

Received in revised format

February 162016

Accepted March 182016

Available online

April 82016

Keywords:

Cash flow

Leverage A B S T R A C T

Cash flow and leverage are two main components of any business firms. A good level of cash flow and leverage shows a desirable performance for business organizations. This paper presents an empirical investigation to study the relationship between combined leverage and cash flow in terms of board of director's ownership and corporate governance structures. The study selects 86 randomly selected firms listed on Tehran Stock Exchange over the period 2009-2013. Using some statistical tests, the survey has indicated that there was a meaningful relationship between leverage and cash flow for firms with different corporate governance structures. The study has also determined that there was a meaningful relationship between leverage and cash flow for firms with different board of director's ownerships.
\end{abstract}

Tehran Stock Exchange
C 2016 Growing Science Ltd. All rights reserved.

\section{Introduction}

When firms intend to the implementation of debt finance, they may reallocate some expected future cash flows away from equity claimants in exchange for existing cash (Bruns \& Merchant, 1990; Myers, 2001). The elements that drive this decision remain elusive in spite of a lot of existing studies (Frank \& Goyal, 2009). This comes from the fact that many of the empirical investigations are focused at providing support for a special theory (Christie \& Zimmerman, 1994). The amount of evidence is big, and so it is an easy task to obtain some empirical support for most ideas. According to Bates et al. (2009) "The average cash-to-assets ratio for U.S. industrial firms more than doubles from 1980 to 2006. A measure of the economic importance of this increase is that at the end of the sample period, the average firm can retire all debt obligations with its cash holdings". Frank and Goyal (2009) investigated the relative importance of some factors in the capital structure decisions of publicly traded American companies over the period 1950-2003 and reported no meaningful relationships for the effect of firm size, the market-to-book ratio, and the impact of inflation.

* Corresponding author. Tel: +989124759473

E-mail address: majafari22@gmail.com (S. M. Jafari)

C 2016 Growing Science Ltd. All rights reserved.

doi: $10.5267 /$ j.ac.2016.4.001 
Huang and Ritter (2009) investigated time-series patterns of external financing decisions and reported that publicly traded U.S. companies fund a much larger proportion of their financing deficit with external equity when the expense of equity capital was low. They offered an econometric model to deal with biases in estimates of the speed of adjustment toward target leverage. They reported that companies could adjust toward target leverage at a medium speed, with a half-life of 3.7 years for book leverage, even after adjusting for the traditional determinants of capital structure and firm fixed effects.

Korteweg (2010) estimated the market's valuation of the net benefits to leverage based on some data over the period 1994-2004, determined from market values and betas of a firm's debt and equity. In their study, small and profitable companies had high optimal leverage ratios, as forecasted by theory, but on the contrary to existing empirical results. Firms are on average slightly under-levered relative to the optimal leverage ratio at refinancing. Leary (2009) investigated the relevance of capital market supply frictions for corporate capital structure decisions. He reported that an expansion in the availability of bank loans, leverage ratios of bank-dependent firms could substantially increase relative to firms with bond market access.

Shyam-Sunder and Myers (1999) examined traditional capital structure models versus the alternative of a pecking order model of corporate financing. They reported that their tests had the power to reject the pecking order against alternative tradeoff hypotheses. Strebulaev (2007) used a calibrated dynamic trade-off model to simulate companies' capital structure paths and suggested a rethinking of the way capital structure tests. Faulkender et al. (2012) recognized that cash flow realizations could provide opportunities to adjust leverage at relatively low marginal cost. Kim and Kross (2005) studied the relationship between earnings and one-year-ahead operating cash flows over the period 1973-2000 and reported that the relationship between current earnings and future operating cash flows had increased over time.

Carpenter and Guariglia (2008) recommended that the significance of cash flow could come from its role in capturing the impacts of credit frictions. Beatty and Weber (2003) investigated the effects of debt contracting on voluntary accounting method changes. Cohen and Zarowin (2010) demonstrated that that SEO companies engage in real activities manipulation, and the decline in post-SEO performance was more severe than that because of accrual management. Their evidence was essential, because it indicated that post-SEO operating underperformance was driven not only by accrual reversals, but also it could reflect the real consequences of operational decisions made to manage earnings.

Dechow and Skinner (2000) investigated the fact that accounting academics could have various perceptions of earnings management than could practitioners and regulators. They also explored the reasons for these various perceptions, and argued that each of these groups could take advantage of some rethinking of their views about earnings management. Fudenberg and Tirole (1995) constructed a theory of income smoothing according to the managers' concern about keeping their position or preventing interference, and on the idea that current performance gains more weight than past performance when one is evaluating the future. They reported that both dividends and income reports could be smoothed and that dividends could convey information not present in the income report.

\section{The proposed study}

This paper presents an empirical investigation to study the relationship between combined leverage and cash flow in terms of board of director's ownership and corporate governance structures. The study selects some randomly selected firms listed on Tehran Stock Exchange over the period 2009-2013. The population of the survey consists of the firms whose fiscal year ended, March, was not added/delisted from stock exchange with no more than 3 months of interruption on trading shares. In addition, the study did not include any holding or financial firm for the population of the survey. Therefore, we have chosen 205 qualified firms out of 636 publicly traded firms. The sample size is calculated as follows, 


$$
n=\frac{N \times z_{\alpha / 2}^{2} \times p \times q}{\varepsilon^{2} \times(N-1)+z_{\alpha / 2}^{2} \times p \times q},
$$

where $N$ is the population size, $p=1-q$ represents the yes/no categories, $z_{\alpha / 2}$ is CDF of normal distribution and finally $\varepsilon$ is the error term. Since we have $p=0.5, z_{\alpha / 2}=1.96$ and $N=205$, the number of sample size is calculated as $n=86$. The study considers two groups of organizational structure for the study. The first group is associated with external governance structure (group 1) and the information of this group is based on the percentage of free float shares and percentage of the institutional investors. The second group is associated with internal governance structure (group 2) and the information of this group is based on ratio of non-executive members of the board of directors and stocks owned by the board of directors. The study also considers two ratios of combined leverage $(D C L Q)$ and free cash flow $\left(C F_{i, t}\right)$, which are calculated as follows,

$$
\begin{aligned}
& D C L_{Q}=\frac{Q(P-V C)}{Q(P-V C)-F C-I-T}, \\
& C F_{i, t}=\frac{\text { Total cash flows reported in the statement of cash flows }}{\text { Total assets }},
\end{aligned}
$$

where $Q, P, V C, F C, I$ and $T$ represent production quantity, selling price, variable cost, fixed cost, interest and tax, respectively. The implementation of Kolmogorov-Smirnov has indicated that all variables of the survey were normally distributed. Therefore, we use parametric tests to examine the hypotheses of the survey.

\section{The results}

\subsection{The first hypothesis}

The first hypothesis of the survey investigates the relationship between cash flow and combined leverage for firms based on the ratio of non-executive members of the board of directors. Table 1 shows some basic statistics associated with this hypothesis.

\section{Table 1}

The results of some basic statistics of two groups

\begin{tabular}{ccccc}
\hline & Number & Mean & Standard deviation & Standard error \\
\hline Group 1 & 69 & 0.8406 & 0.76923 & 0.09587 \\
Group 2 & 69 & 0.4326 & 0.63425 & 0.06524 \\
\hline
\end{tabular}

As we can observe from the results of Table 1, there are some differences between the mean and standard deviation of two groups. Table 2 demonstrates the results of F-test and t-test for two groups.

Table 2

The summary of t-test and F-test

\begin{tabular}{ccccccccc}
\hline & \multicolumn{3}{c}{ Variance } & \multicolumn{3}{c}{ t-test } \\
\cline { 2 - 8 } & $\mathrm{F}$ & $\mathrm{s}$ & $\mathrm{t}$ & $\mathrm{df}$ & $\mathrm{sig}$ & $\begin{array}{c}\text { Mean } \\
\text { Difference }\end{array}$ & $\begin{array}{c}\text { Std. Error } \\
\text { Difference }\end{array}$ \\
\hline$\sigma_{1}^{2}=\sigma_{2}^{2}$ & 2.488 & 0.815 & 4.256 & 68 & 0.000 & 0.6854 & 1.41963 \\
$\sigma_{1}^{2} \neq \sigma_{2}^{2}$ & & & & 4.256 & 65.274 & 0.000 & 0.1745 & 1.37854 \\
\hline
\end{tabular}

As we can observe from the results of Table 2, there is a meaningful difference between two groups. Therefore, the first hypothesis of the survey has been confirmed. 


\subsection{The second hypothesis}

The second hypothesis of the survey investigates the relationship between cash flow and combined leverage for firms based on the ratio of stocks owned by the board of directors. Table 3 shows some basic statistics associated with this hypothesis.

Table 3

The results of some basic statistics of two groups

\begin{tabular}{ccccc}
\hline & Number & Mean & Standard deviation & Standard error \\
\hline Group 1 & 69 & 0.43 & 0.45875 & 0.08654 \\
Group 2 & 69 & 0.34 & 0.68475 & 0.07598 \\
\hline
\end{tabular}

As we can observe from the results of Table 3, there are some differences between the mean and standard deviation of two groups. Table 4 presents the results of F-test and t-test for two groups.

Table 4

The summary of t-test and F-test

\begin{tabular}{cccccccc}
\hline & \multicolumn{2}{c}{ Variance } & \multicolumn{5}{c}{ t-test } \\
\cline { 2 - 8 } & $\mathrm{F}$ & $\mathrm{sig}$ & $\mathrm{t}$ & $\mathrm{df}$ & $\mathrm{sig}$ & $\begin{array}{c}\text { Mean } \\
\text { Difference }\end{array}$ & $\begin{array}{c}\text { Std. Error } \\
\text { Difference }\end{array}$ \\
\hline$\sigma_{1}^{2}=\sigma_{2}^{2}$ & 2.875 & 0.236 & 4.236 & 68 & 0.000 & 0.6847 & 1.2354 \\
$\sigma_{1}^{2} \neq \sigma_{2}^{2}$ & & & 4.784 & 60.278 & 0.000 & 0.8785 & 1.6547 \\
\hline
\end{tabular}

As we can observe from the results of Table 4, there is a meaningful difference between two groups. Therefore, the second hypothesis of the survey has been approved.

\section{Discussion and Conclusion}

In this survey, we have performed an empirical investigation to study the effect of ownership structure on relationship between combined leverage and cash flow in publicly traded firms on Tehran Stock Exchange. The results of this survey have indicated that ownership structure played an important role on relationship between cash flow and combined leverage. As stated by Bates et al. (2009), many US firms have increased their cash flow over the past decades, which created the power to retire their liabilities sooner than expected. Lemmon and Lins (2003) studied the effect of ownership structure on value on the event of the region's financial crisis on a sample of 800 firms in eight East Asian countries. They reported that the crisis negatively influenced on firms' investment opportunities, raising the incentives of controlling shareholders to expropriate minority investors. Fan and Wong (2002) investigated the relationships between earnings informativeness, computed by the earnings-return relation, and the ownership structure of some firms in Asian economies. The results were consistent with two complementary explanations. First, concentrated ownership and the associated pyramidal and cross-holding structures built agency conflicts on the relationship of controlling owners and outside investors. As a result, controlling owners were perceived to report accounting information for selfinterested purposes, imposing a loss on credibility to outside investors. In addition, concentrated ownership was related to low earnings informativeness as ownership concentration prevented leakage of proprietary information about the firms' rent-seeking activities, which were prevalent and profitable in the selected firms in Asia. Ho and Wong (2001) performed a comprehensive study on the relationship between corporate governance structures and the extent of voluntary disclosure.

The results of this survey could shed light into the fact that investors could be cautious when they invest in firms with unusual structural ownership. As emphasized by Laeven and Levine (2008) and Vafeas and Theodorou (1998), capital ownership plays an important role for financial performance and such 
studies must be repeated to better understand the effect of capital ownership on firms listed in Tehran Stock Exchange.

\section{Acknowledgement}

The authors would like to thank the anonymous referees for constructive comments on earlier version of this paper.

\section{References}

Altınkılıç, O., \& Hansen, R. S. (2000). Are there economies of scale in underwriting fees? Evidence of rising external financing costs. Review of Financial Studies, 13(1), 191-218.

Bates, T. W., Kahle, K. M., \& Stulz, R. M. (2009). Why do US firms hold so much more cash than they used to?. The Journal of Finance, 64(5), 1985-2021.

Beatty, A., \& Weber, J. (2003). The effects of debt contracting on voluntary accounting method changes. The Accounting Review, 78(1), 119-142.

Bruns, W. J., \& Merchant, K. A. (1990). The dangerous morality of managing earnings. Management Accounting, 72(2), 22-25.

Carpenter, R. E., \& Guariglia, A. (2008). Cash flow, investment, and investment opportunities: New tests using UK panel data. Journal of Banking \& Finance, 32(9), 1894-1906.

Christie, A. A., \& Zimmerman, J. L. (1994). Efficient and opportunistic choices of accounting procedures: Corporate control contests. Accounting Review, 69(4), 539-566.

Cohen, D. A., \& Zarowin, P. (2010). Accrual-based and real earnings management activities around seasoned equity offerings. Journal of Accounting and Economics, 50(1), 2-19.

Dechow, P. M., \& Skinner, D. J. (2000). Earnings management: Reconciling the views of accounting academics, practitioners, and regulators. Accounting Horizons, 14(2), 235-250.

Fan, J. P., \& Wong, T. J. (2002). Corporate ownership structure and the informativeness of accounting earnings in East Asia. Journal of accounting and economics, 33(3), 401-425.

Faulkender, M., Flannery, M. J., Hankins, K. W., \& Smith, J. M. (2012). Cash flows and leverage adjustments. Journal of Financial Economics, 103(3), 632-646.

Fudenberg, D., \& Tirole, J. (1995). A theory of income and dividend smoothing based on incumbency rents. Journal of Political Economy, 103(1), 75-93.

Frank, M. Z., \& Goyal, V. K. (2009). Capital structure decisions: which factors are reliably important?. Financial Management, 38(1), 1-37.

Ho, S. S., \& Wong, K. S. (2001). A study of the relationship between corporate governance structures and the extent of voluntary disclosure.Journal of International Accounting, Auditing and Taxation, 10(2), 139-156.

Huang, R., \& Ritter, J. R. (2009). Testing theories of capital structure and estimating the speed of adjustment. Journal of Financial and Quantitative Analysis, 44(02), 237-271.

Kim, M., \& Kross, W. (2005). The ability of earnings to predict future operating cash flows has been increasing - not decreasing. Journal of Accounting Research, 43(5), 753-780.

Korteweg, A. (2010). The net benefits to leverage. The Journal of Finance,65(6), 2137-2170.

Laeven, L., \& Levine, R. (2008). Complex ownership structures and corporate valuations. Review of Financial Studies, 21(2), 579-604.

Leary, M. T. (2009). Bank loan supply, lender choice, and corporate capital structure. The Journal of Finance, 64(3), 1143-1185.

Lemmon, M. L., \& Lins, K. V. (2003). Ownership structure, corporate governance, and firm value: Evidence from the East Asian financial crisis.The journal of finance, 58(4), 1445-1468.

Myers, S. C. (2001). Capital structure. The Journal of Economic Perspectives, 15(2), 81-102.

Shyam-Sunder, L., \& Myers, S. C. (1999). Testing static tradeoff against pecking order models of capital structure. Journal of Financial Economics,51(2), 219-244. 
Strebulaev, I. A. (2007). Do tests of capital structure theory mean what they say?. The Journal of Finance, 62(4), 1747-1787.

Vafeas, N., \& Theodorou, E. (1998). The relationship between board structure and firm performance in the UK. The British Accounting Review,30(4), 383-407. 